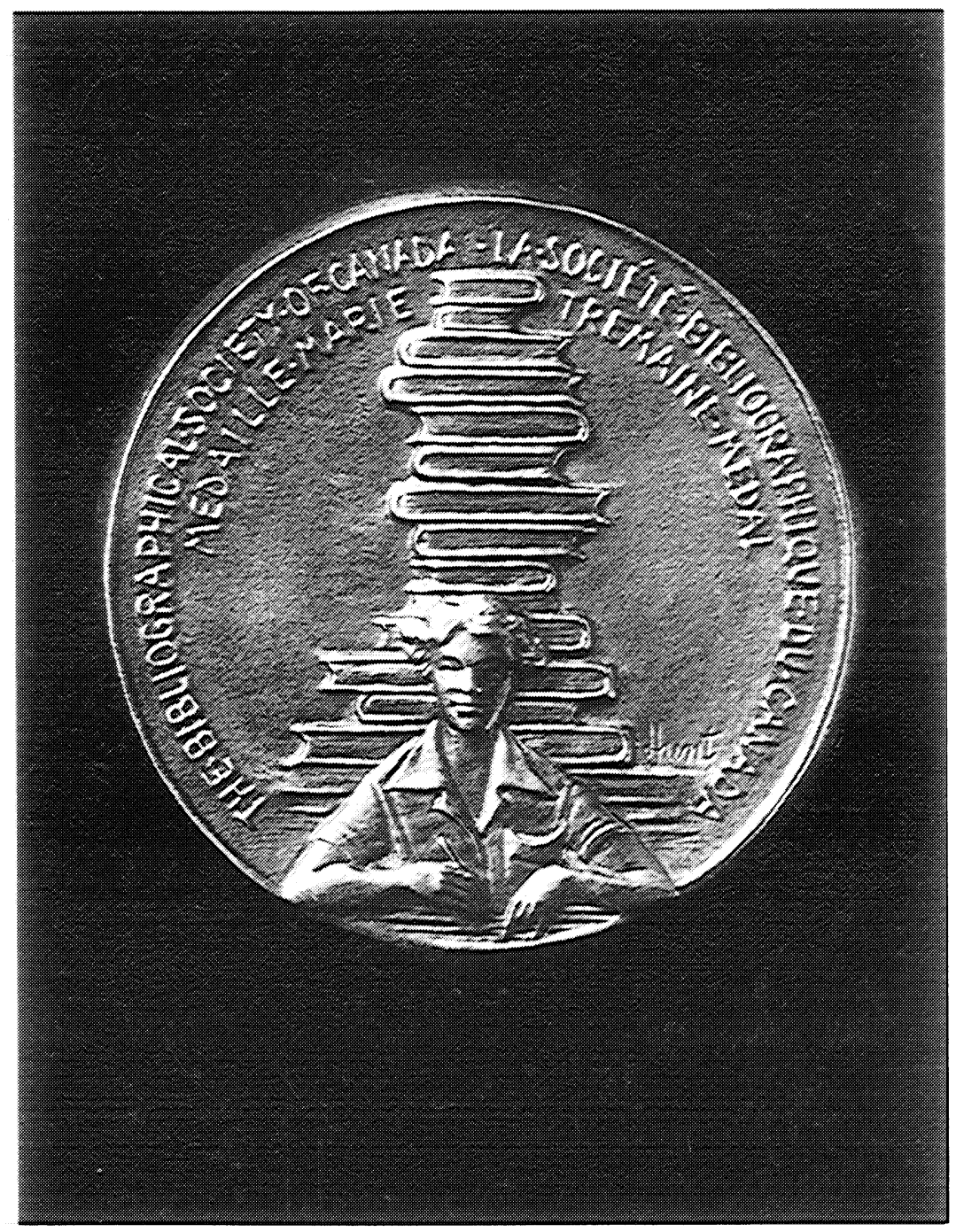

The Marie Tremaine Medal / Médaille Marie Tremaine commissioned from Canadian medallist Dora de Pédery-Hunt. 


\section{The Tremaine Medal}

The Marie Tremaine Medal of the Bibliographical Society of Canada was established in I970 to honour outstanding service to Canadian bibliography and distinguished publication in either English or French in that field. The first recipient was Marie Tremaine herself, whose contributions to Canadian bibliography were celebrated in volume xxIII of the Papers. The first medal, designed by Peter Dorn and incorporating the distinctive logo that Mr. Dorn also designed for the Society, is illustrated in volume IX of the Papers.

In 1973 the Medal was awarded jointly to John Hare and Jean-Pierre Wallot for their compilation Les Imprimés dans le Bas Canada, 1801-1810 (1967). The I 975 recipient was Bruce Braden Peel, whose Bibliography of the Prairie Provinces to 1953 (1956; 2d ed., 1973) is the standard reference work in its field, and who has also published studies of early printing in the Red River Settlement and the Rossville Mission Press. In 1977 the Medal was awarded to William F.E. Morley for his many contributions to Canadian bibliography, including the series Canadian Local Histories to 1950 (University of Toronto Press) and A Bibliographical Study of Major John Richardson (1973).

Just a few months before his death in 1979, Reginald Eyre Watters received the Tremaine Medal in recognition of his landmark work, $A$ Checklist of Canadian Literature and Background Materials, 1628-1960 (1959; 2d ed., I972), and other contributions to the study of Canadian literature. Olga Bernice Bishop, recipient of the I98 I Medal, is well known for her valuable bibliographies of early Canadian government documents and for the two-volume Bibliography of Ontario History, 1867-1976, Cultural, Economic, Political, Social (I980). In I983 the Tremaine Medal was awarded to the distinguished urban historian Alan F.J. Artibise, whose publications include the bibliographical guides Western Canada since 1870 (I978) and Canada's Urban Past (I98I). Douglas Grant Lochhead was the I985 recipient; his contributions to Canadian bibliography are highlighted in the citation that follows.

Until I 985 the Marie Tremaine Medal was presented biennially, but in 
that year the Council, in recognition of increasing bibliographical activity in Canada in recent years, decided to make it an annual award, although no medal was awarded in I986. In I985 it was no longer possible to have the medal made according to the original design because of technical difficulties. A new medal was commissioned from the noted Canadian medallist Dora de Pédery-Hunt. Mrs. Hunt, inspired by the seriousness of Marie Tremaine's work and by her personal qualities, nonetheless wished to bring a touch of humour into her design for the medal because she was convinced that a sense of humour must have aided Dr. Tremaine in her vast undertakings. She depicted Dr. Tremaine at work with an unruly pile of books watching over her.

The Society welcomes nominations for the Medal. They must be supported by a biographical note, a list of principal publications, and other relevant information, and should be sent to the Tremaine Medal Committee, in care of the current chairman or the Secretary-Treasurer of the Society. The deadline is January 3 ist of each year. Members of the Council of the Society are not eligible for the award while they are in office.

THE I985 TREMAINE MEDAL

At the Annual Meeting in I985, the following citation was read by Gloria M. Strathern on behalf of the Society:

Ladies and gentlemen:

The Council of the Bibliographical Society of Canada, on the unanimous recommendation of its Tremaine Medal Committee, has chosen to award this year's Marie Tremaine Medal in Canadian Bibliography to Douglas Grant Lochhead.

Professor Lochhead is a graduate of McGill and the University of Toronto with degrees in English and Library Science. His professional career has taken him to the University of Victoria; Cornell; Dalhousie, where he was University Librarian; and York University, where he was the first Director of Libraries. From 1963 to 1975 he was Professor of English and Librarian of Massey College in the University of Toronto. For the past decade he has been Davidson Professor of Canadian Studies and Director of the Centre for Canadian Studies at Mount Allison University in Sackville, New Brunswick.

But a mere recitation of places and dates tells us little about the individual we honour today. Professor Lochhead's contributions to Canadian bibliography, indeed to Canadian culture, are numerous and diverse. His interests in the graphic arts have ranged from this country's first printers to the practitioners of today. He has written about Anthony Henry and the 
shadowy Herbert Jefferie, of eighteenth-century Halifax, and Lovell \& Gibson, of nineteenth-century Montreal; about John Ross Robertson, Toronto 'publisher for the common reader,' and Andrew King, Saskatchewan printer of show posters; about Carl Dair, designer of Cartier, Canada's first text typeface, and Saul Field and David Silverberg, contemporary printmakers. In recent years, he has been continuing the work of Marie Tremaine, after whom this Medal is named, in a study of eighteenthcentury printers' ornaments based on her celebrated bibliography.

Believing that printing is best understood through a 'happy working of the head and hand,' Douglas Lochhead in 1963 established Canada's first bibliographical press in the Library of Massey College. There a representative collection of nineteenth-century presses, type, and other equipment is preserved for the study of traditional printing techniques and the instruction of future bibliographers. Through his teaching many students have been challenged to explore new fields of research.

This Society also owes a great debt to Professor Lochhead, who was its Chairman of Publications from I96I to I972, a period that saw the appearance of a number of important monographs and reprints, including the revised second edition of the Bibliography of Canadian Bibliographies. He was the moving force behind two successful colloquia held in Toronto in I 97 I and 1973, and he served as President of the Society from I 974 to 1976.

Outside the Society he has done much to make Canada's literature and history known. With Shirley Elliott, he founded the Atlantic Provinces Checklist in 1957. He played an important role in the establishment of the Canadian Institute for Historical Microreproduction in 1978. He has been general editor of two series of reprints for the University of Toronto Press, and with Raymond Souster, he compiled two anthologies of Canadian poetry. In I983-84 he served both Canada and the land of his ancestors as Visiting Professor of Canadian Studies at the University of Edinburgh. He continues to make his own special contribution to Canadian literature - his many fine poems, published in journals and a dozen separate volumes.

Ladies and gentlemen, it is our great privilege to recognize the achievements of Douglas Grant Lochhead, poet, printer, and bibliographer. 